\title{
Wapenskoutragedie op Kuruman
}

\section{Mnr Kobus Willers*}

\begin{abstract}
'God Almighty, it is a bomb!' het John Frylinck so hard as wat hy kon geskreeu, toe hy die vallende voorwerp onder die vliegtuig sien. Sy konsternasie is veroorsaak deurdat dit gelyk het of die vliegtuig bokant ' $n$ deel van die skare toeskouers by die wapenskou is. Frylinck, wat voorheen militêre diens in Oos-Afrika gedoen het, het daar heelwat vliegtuie wat bombarderings gedoen het, gesien. Hy het dus ' $n$ vallende bom herken as hy een sien.
\end{abstract}

Die artikel in Paratus van Julie 1990 oor die vermiste vaandel van die Kuruman-Kommando wat in 1938 bestel is en eers 'n halfeeu later tydens die eeufees van die dorp oorhandig is, nadat dit met die uitbreek van die Tweede Wêreldoorlog in 1939 vermis geraak het, roep 'n ander tragiese gebeurtenis voor die gees waarby hierdie Kommando betrokke was.

'n Wapenskou was met die toestemming van die Departement van Verdediging deur die Kuruman-Kommando gereël, om saam te val met die viering van Uniedag 31 Mei 1924. Die uittredende bevelvoerder was senior kommandant It Kol J.A. van Zyl, dieselfde Koos van Zyl wat met sy Kuruman-Kommando so voortreflik in die Suidwes-veldtog in 1914-18 opgetree het. Die tentelaer van die kommando was sowat twee kilometer noordwes van die dorp opgeslaan. Een van die hoogtepunte van die wapenskou sou 'n demonstrasie wees deur die jong Suid-Afrikaanse Lugmag (wat in 1920 ontstaan het), van vliegtuie wat bomme sou neerlaat asook 'n Lewismasjiengeweer-aanval op teikens wat op 'n veilige afstand van die kamp en die skare belangstellendes opgerig was.

Daar het wye belangstelling onder die publiek geheers, wat oor lang afstande uit die Kalahari en omgewing met perdekarre, donkie- en ossewaens en motors gekom het na dit wat vir hulle 'n buitengewone ondervinding sou wees. Staanplekke vir voertuie en toeskouers was ordelik op ' $n$ veilige afstand ingeruim en onder toesig geplaas. Die gebied was baie geskik, aangesien dit lae randjies aan drie kante van die sanderige laagte waarop die landingsbaan vir die vliegtuie uitgelê is, gehad het. Laasgenoemde baan was op 'n gereserveerde stuk grond wat tot verbode gebied verklaar is.

Op Zwartkop-lugstasie buite Pretoria ontvang It F.H. Hiscock bevel om met It Pierre Joubert in twee De Havilland (DH9) vliegtuie op 26 Mei 1924. om 09:30 na Kimberley te vertrek en daar aan die distrikstafoffisier te rapporteer. Lugwerk- tuigkundige Ford vergesel It Joubert. Hulle kom om 13:40 op Kimberley aan waar Hiscock in opdrag die Wesselton-diamantmyn uit die lug fotograveer.

Die twee vliegtuie vertrek op 27 Mei na Kuruman om die demonstrasie by die wapenskou waar te neem. Daar sou hulle een 112 pond en twee 20 pond bomme laat val en twee dromme Lewismasjiengeweerammunisie afvuur.

Lt kol W.J. Klerck OBE van die SA Stafkorps het as passasier saam met It Hiscock van Kimberley af vertrek. Hiscock lei die vlug. Hy raak egter sy koers kwyt omdat hy geen vlugkaart van Kuruman se ligging gehad het nie. Hulle bevind hulle naderhand bokant Olifantshoek wat Joubert herken het en gooi hy boodskappe af om te sê hulle het verdwaal. Nadat hulle vir ongeveer 'n halfuur oor die Langeberg gesirkel het, kies hulle koers in die rigting van Postmasburg.

Joubert se DH9 raak eerste sonder brandstof en hy gee vir Hiscock 'n noodsein dat hy gaan land. Hy voer 'n noodlanding sowat $30 \mathrm{~km}$ noord van Postmasburg uit. Terwyl hy sak om op.'n klein pannetjie neer te stryk, tref sy een bomrak 'n droë boom en ruk een bom af. $\mathrm{Na}$ 'n suksesvolle landing het die vlieënier en Ford die skade vlugtig ondersoek en toe na die bom gaan soek. Hulle tref dit betreklik ongeskonde naby die droë boom aan en dra dit na die vliegtuig waar dit met redelike veiligheid weer aan sy rak gehang kon word. Hulle het dadelik aan die werk gespring om ander minder ernstige skade te herstel. Hulle kon dit nie daardie middag afhandel nie.

Intussen het Hiscock met die oorblywende brandstof, sowat vyf km van die dorp af, 'n noodlanding uitgevoer. Hy doen heelwat skade in die proses op nl. 'n gebarste band, 'n gebreekte skroef en 'n beskadigde onderstel. Hulle stap na die dorp om hulp te kry. Hiscock reël met 'n boer om brandstof en olie na Joubert te neem, waar hulle laat aankom as gevolg van vyf papwiele in die veld opgedoen. Hy help daar tot laat die 
aand en oornag op 'n boereplaas daar naby. Joubert en Ford slaap bibberend van die koue by die vliegtuig in die veld, aangesien dit in Mei al koud word in daardie geweste.

Teen ligdag werk hulle voort met Hiscock se bystand.

Dit was eers om 13:00 dat hulle gereed was om op te styg, wat glad verloop het. Dit neem hom net 45 minute om sy bestemming te bereik. Hy voer 'n goeie landing uit nadat hy 'n paar draaie oor die dorp en die skouterrein gegooi het. Teen daardie tyd was die skare mense al kriewelrig oor die oponthoud, die oorsaak waarvan hulle salig onbewus was. Nou word die aankoms van die vliegtuig toegejuig.

Die bemanning word eers na die dorp geneem vir ' $n$ bad en middagete. Daar besoek die distriksbevelvoerder van die polisie, It BeresfordWood, hulle en willig Joubert in om hom saam op te neem met die demonstrasie.

Op die vliegveld terug vind die gewone roetine ondersoek voor opstyging plaas. Die bomrakke en hangskakels kry besondere aandag. Heel laaste word die knaldoppe ('detonators') in elke bom gelaai sodat dit sou ontplof as dit die grond tref. Dan help Ford die polisiehoof om sy sitplek agter die vlieënier in te neem vir die vlug. Omdat Hiscock se DH9 nie lugwaardig was nie, sou Joubert net sy deel van die demonstrasie uitvoer $\mathrm{nl}$. om twee 20 pond bomme op die voorafbepaalde teiken af te gooi. Voor die vliegtuig opstyg, was daar al 'n demonstrasie van Lewismasjiengeweervuur op 'n teiken weg van die skare af.

Die opstyging in 'n noordwestelike rigting het nie heeltemal glad verloop nie. Eers na drie spronge is die $\mathrm{DH} 9$ die lug in vanweë die toestand van die aanloopbaan.

$\mathrm{Na}$ 'n paar wye draaie draai die vlieënier om, om in 'n reguit lyn sy teiken te nader. Om dit te doen swenk hy eers skerp links en dan regs. Dis toe dat hy ' $n$ voorwerp opmerk wat tussen die skare val en hoor ontplof. Hy merk die geskarrel van mense en besef dat daar ' $n$ ongeluk gebeur het. Hy weet dat hy lank nog nie binne die afstand van die teiken was om die bom te gelos het nie.

Hy draai onmiddellik om, om te land.

Die bom het aan die westekant van die skare geval, waar die mense yler gestaan het. Pandemo- nium het losgebars. Chaos en verwarring, konsternasie en wanorde, verslaentheid en verdriet heers tussen die niksvermoedende toeskouers.

'There was a howl of execration from the crowd - Diamond Field Advertiser, 31 May 1924.

\section{Offisiere probeer die publiek kalmeer.}

Oral lê dooies en gewondes. Bloed vloei vrylik. Klaaggeluide en geween gaan op. Casper van der Walt (54) en sy vrou, Anna (52), lê langs mekaar dood; Gert Erlank (39) en Christina Claassens (10) is ook op slag dood. Later sterf ook Pieter van der Linde en Abraham Erasmus in die Kimberley-hospitaal.

Daar was 36 gewondes waarvan 3 kritiek, 8 ernstig en 25 lig beseer was.

Twee blou karperde lê daar naby dood en ander diere is ook beseer.

Aan die voertuie is daar nie veel skade aangerig nie aangesien slegs een motor se verkoeler beskadig is. Gelukkig was die distriksgeneesheer van Olifantshoek, dr. F.R. Jones ook onder die toeskouers en kon hy en die Kommando se mediese ordonnanse, eerstehulp toepas. Later het dokters Beare en Young van Kuruman ook tot die gewondes se hulp gesnel. So gou as moontlik is 'n tydelike hospitaal op die dorp ingerig, want Kuruman het toe nog nie oor 'n vaste hospitaal beskik nie. Ernstige gevalle is met ambulanse van Kimberley af daarheen geneem en verpleegsusters is geleen om na Kuruman te kom. Twee pasiënte is in die Kimberleyse hospitaal oorlede.

Nadat Joubert geland het, het hy uitgespring en wou hy in sy verwarde toestand na die rampgebied hardloop, maar is vir sy eie veiligheid deur It Beresford-Wood gekeer. Daar is gevrees dat hy aangerand kon word. Die polisiehoof neem beheer oor en beveel dat Joubert in hegtenis geneem en van die terrein verwyder word.

Die aand bring hy in die tronk deur om homself te beskerm, maar is die volgende dag op borgtog van £500 vrygelaat. Die polisie lê op die vliegtuig beslag en laat dit streng bewaak. Ook die kraterarea word afgesper en bewaak.

Kol Klerck wat toe al reeds op Kuruman aangekom het, tree onmiddellik met die owerhede in Pretoria in verbinding. Die Adjudant-Generaal van die Unie se Verdedigingsmag gelas 'n ge- 
regtelike ondersoek wat op Vrydag 30 Mei sitting sou neem en op al die aspekte van die ongelukkige gebeurtenis moes ingaan en terugrapporteer.

Die lede van die ondersoekspan was It kol W.J Klerck OBE, SA Stafkorps as president; mnr C.E. Viljoen, landdros van Kuruman (lid); mnr H.J.C de Jager, prokureur en burgemeester van Kuruman (lid).

Meer as 20 getuies word gedagvaar om te kom getuig. Baie moeite is gedoen om ook getuienis van beseerdes wat nie kon verskyn nie, in te win. Die eerste getuie was dr. Frederick Jones, distriksgeneesheer van Olifantshoek. Hy handig 'n naamlys van oorledenes en beseerdes, soos op daardie stadium, by die Hof in en beskryf saaklik en duidelik wat hy waargeneem het en as geneesheer onder die omstandighede gedoen het.

Die volgende getuie was It Arthur BeresfordWood, SA Polisiebevelvoerder van die Kurumandistrik. Hy was 'n passasier in die vliegtuig waarmee Joubert opgestyg het. Hy beskrywe die voorbereidings wat hy waargeneem het voor opstyging. Hy het nie gesien dat die vlieënier 'n hefboom getrek het om die bom te laat val nie. Eers toe hulle 'n ontploffing hoor en mense sien hardloop, het hulle besef dat daar 'n ongeluk was. Hy beskrywe die stappe wat hy geneem het na hulle landing.

John Frylinck, 'n prokureur in Kuruman, getuig dat hy in Oos-Afrika militêre diens gedoen het en daar baie bomme sien val het. Daarom het hy die vallende voorwerp uit die vliegtuig onmiddellik as 'n bom herken. Die opstyg van die vliegtuig het byna misluk. Hy handig 'n geskrewe verklaring ten gunste van Joubert by die Hof in. Die Hof verdaag toe tot 31 Mei om 'n inspeksie ter plaatse uit te voer. Op versoek van die Hof het die plaaslike landmeter, mnr Dirk Roos, 'n skets van die ongeluksgebied opgestel wat as handleiding kon dien.

Die volgende mense is uitgenooi om die ondersoek te doen: die hoof van die Lugmag, kol Pierre van Ryneveld KBE DSO, kapt Venter DFC (Lugmag), mnr Hammerschlag, prokureur wat Joubert verteenwoordig, Joubert self en landmeter Dirk Roos.

Die belangrikste getuienis was dié van kol Van Ryneveld. Hy skets hoe Joubert by die SA Lugmag aangesluit het na 100 uur vliegondervinding in die RAF sedert 1917. Hy kom na Roberts
Heights (Voortrekkerhoogte) op 7 Januarie 1924 op ' $n$ opknappingskursus as vlieënier in die spesiale reserwemag. Sy kursus sluit teoretiese en praktiese opleiding in bomme en bomwerping in. Hy toon bogemiddelde kwaliteite waarop hy kwalifiseer vir die rang van luitenant. Hy voeg nog 40 uur vliegtyd by sy vorige 100 uur. Hy prys hom aan as ' $n$ standvastige en betroubare vlieënier; die rede waarom hy vir hierdie sending gekies is.

Tydens die in loco inspeksie van die Hof verduidelik kol Van Ryneveld tegniese aspekte van die bommeganisme, hantering en samestelling daarvan en gee spesiale aandag aan die gebuigde haak van bomrak nr. 1. Sy tegniese uiteensetting en die omstandighede wat kon lei tot die val van 'n bom was baie breedvoerig. Die moontlikheid dat die skakelring self ook beskadig kon gewees het tydens die noodlanding, kon nie buite rekening gelaat word nie. Hy was van mening dat die ongeluk voorkom kon word as daar nie oor die skare gevlieg was nie, soos verbied word deur die staande regulasies. Lt Hiscock erken aan die Hof dat hy sonder vlugkaart van Kimberley na Kuruman probeer vlieg en daarom verdwaal het

Lt Joubert meld sy ondervinding by die RAF in sy getuienis en sy aansluiting by die SA Lugmag. Hy beskrywe sy noodlanding en ook die ongeluk met die bom. Hy is oortuig dat hy nie die bom doelbewus laat val het nie en dat dit werklik 'n ongeluk was. 'I say the whole thing was an absolute accident, and I was just the instrument of fate,' het hy voor die Hof gesê.

Mnr Danie van Vuuren, 'n boer van die plaas Toxteth tussen Kuruman en Taung, getuig dat hy en sy broer David, ook uit sy omgewing, die wapenskou met hulle gesinne bygewoon het. Hy was sowat 10-15 tree van die plek af waar die bom ontplof het en het kort tevore nog met die egpaar Van der Walt gepraat.

Een van David se seuns, Danie, het na matriek op Kuruman die lugmag as loopbaan gekies en as kol D.J.J.C. van Vuuren afgetree nadat hy onder meer in Korea diens gedoen het. Ander getuies was: sp-sers Christiaan van Vuuren, James Moorcroft (boer), Jan Nel (timmerman van Kuruman), Adam Barnard (onderwyser op Dingle), Tom Mellville (agent en afslaer op Kuruman) en Christian de Klerk uit die distrik Hay. Geeneen van die getuies kon sien dat die vlieënier ' $n$ hefboom aan die buitekant van sy sitplek trek om die bom te laat val nie. 
Die Hof reik sy bevinding op 4 Junie uit. Twee moontlike oorsake van die ongeluk is oorweeg: (a) dat die skakel waaraan die bom gehang het beskadig is tydens die noodlanding naby Postmasburg en (b) dat die loods 'n oordeelsfout begaan het.

Die Hof betwyfel eersgenoemde en is van mening dat die bom losgeraak het toe die vlieënier geswenk het om in 'n reguit lyn te kom met sy teiken. Die werklike oorsaak was nog steeds vir die Hof onbekend. Die Hof wou nie aanvaar dat dit 'n ongeluk was nie.

Om die bevinding op te som word die slotparagrawe uit die hofverslag woordeliks aangehaal: 'In view of all the circumstances and after very careful and serious consideration, the Court, in the absence of any definite evidence to guide it, is not prepared to say that the unfortunate and regrettable occurrence was or was not an accident.

'The Court at the same time, however, feels strongly that this catastrophe would have been avoided had the pilot (Joubert) acted strictly in accordance with the Standing Orders of the SA Air Force, and kept well clear of the crowd all the time he was in the air.'

Dit word dus aan die twee betrokke ministers (Verdediging en Justisie) oorgelaat om tot 'n finale besluit te kom.

Die saak Rex vs Joubert dien dan ook voor die Hooggeregshof in Kimberley, wat met sy uitspraak, 'Joubert was entirely exonerated from blame', die saak afsluit.
Die Diamond Fields Advertiser het in sy uitgawe van 31 Mei 1924 wye dekking aan die ongeluk gegee, onder opskrifte soos: 'The Kuruman Wapenschouw; Graphic History of the Bombing Tragedy; Eventful Flight from Kimberley; The Fatal Bomb Dropped'.

Die blad berig dat kol Klerck die aand na die ongeluk lede van die Kommando toegespreek het en dat politieke leiers soos dr D.F. Malan, Bruckner de Villiers, kol Deneys Reitz e.a. ook teenwoordig was. Dit was op die vooraand van die 1924-verkiesing en die veldtog was in volle gang. By die begrafnis van oorledenes is ' $n$ lang telegram van medelye van genl Smuts uit Bloemfontein voorgelees.

'n Paar jaar na die ongeluk het Joubert uitgetree. Met die uitbreek van die oorlog in 1939, sluit hy egter weer aan by die SALM. Hy word na die RAF oorgeplaas. Hy het nie as vegtersloods gevlieg nie maar baie vlugte ('ferry flights') met vragvliegtuie onderneem soos ondermeer die vervoer van valskermsoldate bv. in die slag in Arnhem. Toe die vrede in 1945 aanbreek was hy nog in Engeland. Op die vooraand van sy terugkeer na Suid-Afrika was hy in 'n ontploffing betrokke wat hom sy lewe gekos het. Hy is in Bath begrawe. Weer eens was hy 'the instrument of fate'.

${ }^{*} \mathrm{Mnr}$ J.B. Willers is 'n vryskutjoernalis.

\section{Verwysings}

1. DDOKD.

2. Mondelinge inligting van verskeie persone. 